PART TWO

HISTORIOGRAPHY 
T. Rood - 9789047422938

Downloaded from Brill.com04/26/2023 09:03:41AM via free access 


\section{GHAPTER SEVEN}

\section{HERODOTUS}

\section{T. Rood}

At the start of his work, Herodotus writes that 'among the matters covered is, in particular, the cause of the hostilities between Greeks and non-Greeks'. ${ }^{1}$ He goes on to relate the causes of the conflict according to 'learned Persians' - a story of the seizure of women (Io, Europa, Medea, Helen) with the final kidnapping leading to the Trojan Warand a variant Phoenician story of the circumstances under which Io came to abandon her native Argos (I.I-5). This Persian story, revolving around events before and up to the time of the Trojan War, is then contrasted with the events that Herodotus marks as the start of his story proper:

I will talk about the man who, to my certain knowledge, first undertook criminal acts of aggression against the Greeks. I will show who it was who did this, and then proceed with the rest of the account ... Croesus was Lydian by birth ... He was the first non-Greek we know of to have subjected Greeks to the payment of tribute, though he made alliances with some of them ... Before Croesus' reign, all Greeks were free.

$$
(\mathrm{I} \cdot 5 \cdot 3-6.3)
$$

No sooner has Herodotus made this claim, however, than he qualifies it by explaining why he has not started with an earlier incursion against the Greeks: 'the Cimmerian expedition which reached Ionia before Croesus' time was a raiding party, intent on pillage, and not a conquest of the communities there' (ı.6.3). Another external analepsis follows as Herodotus proceeds to tell the story of how rule over the Lydians had passed from the Heraclidae to Croesus' family, the Mermnads, and to narrate the noteworthy incidents in the reigns of Croesus' predecessors - incidents that include earlier cases of conflict with the Greeks (the war between Lydia and Miletus, for instance, which Croesus' father Alyattes inherited from his father Sadyattes) as

1 Translations are mostly from Waterfield (Oxford World's Classics). All dates are $\mathrm{BC}$ and all references to Herodotus unless otherwise stated. 
well as more peaceful interaction ('as far as we know, Gyges [the first Mermnad ruler] was the first non-Greek to dedicate offerings at Delphi since the Phrygian king Midas', I.I4.2).

Dionysius of Halicarnassus praised Herodotus' choice of the beginning and end of his history: 'he begins with the reasons why the barbarians injured the Greeks in the first place, and proceeds until he has described the punishment and the retribution which befell them: at which point he ends' (Pomp. 3). But Herodotus' disposition of material at the start of his work complicates his definition of Croesus' reign (56o) as the start of his story. It is not just that he contrasts his story of Croesus' subjection of the Ionians with the Persian variant about the seizure of Asiatic and Greek women. It is also that he gives the background to Croesus' subjection of the Greeks by explaining how Croesus' family came to power and by showing how Croesus' predecessors had interacted with the Greeks. The chain of causation means that it is impossible to isolate one event as the start of the story. And the allusion to Gyges' dedications at Delphi offers a different beginning to another story, the story of the offerings made by eastern kings at Delphi (and here Herodotus is prepared to allow the sort of 'mythical' precedentMidas' dedications - that he was reluctant to tolerate when explaining the development of conflict between East and West).

Herodotus also complicates Dionysius' patriotic reading of his choice of an ending for his story. He continues the story of Greek-Persian hostility beyond the battles of Plataea and Mycale, both fought in 479, by narrating the events of the rest of that year, as the Athenians - under the generalship of Xanthippus, father of Pericles - start to assume the leading role in pressing the war against Persia in the eastern Aegean. Herodotus concludes with the statement 'Nothing further happened for the remainder of the year' (9.I2I) - and with an analeptic account of a proposal put to Gyrus that the Persians should move to a less rough land. The proposal was made by Artembares - an ancestor of the Artayctes whom the Athenians have just crucified at the richly symbolic setting of the Hellespont - on 'the shore on which Xerxes' bridge across the straits had ended' (9.I20.4). Herodotus' story ends with strong hints that a new story of the Athenian rise to power is starting: nothing further may have happened in that year, but the story of the Athenian rise to naval hegemony would continue. ${ }^{2}$

2 The end of Herodotus' work has been much discussed in recent years: cf. Boedeker ı988; Herington ı99г; Moles I996; Dewald ı997; Pelling ı997; and Flower \& 
At the same time, Herodotus' ending further undermines the opening of his story. The fact that Artayctes is punished for despoiling the shrine of Protesilaus (9.116, I20.4) provides a sense of an ending by looking back to the Trojan War - the beginning of Greco-barbarian hostilities highlighted by the 'learned Persians' at the start of the work. Herodotus seems to be suggesting that the Trojan War might after all have been an appropriate beginning for his story. Indeed, he had earlier compared the size of Xerxes' army with Agamemnon's and described how Xerxes visited Troy on his way to Greece (7.20.2, 43.I).

The difficulty of marking the end of Herodotus' story is further underlined by numerous external prolepses. These prolepses look ahead both to events involving Greeks and non-Greeks (e.g. 7.Io6-I07, I5I) and to the increased tensions among the Greeks in the years after their successful resistance to Persia (e.g. 7.137; 8.3.2; 9.35.2, 37.4, 64.2, 73.3 , I05). The accumulation towards the end of the work of prolepses narrating fighting between Greeks in the years between the Persian and Peloponnesian Wars and even events in the Peloponnesian War is an eloquent way of suggesting how the internal tensions that marked the Greeks' resistance to Persia later escalated into war between the states that had played the leading role in the Persian Wars.

Defining Herodotus' story is also made problematic by his practice of reporting variant versions. ${ }^{3}$ As well as creating a parallel metanarrative about the way in which tales about the past are transmitted, this practice destabilizes the notion of a single story. And even when Herodotus does not tell variants he does not necessarily guarantee the truth of what he reports: he sometimes claims to report what is told without necessarily believing it (2.123.I; 7.I52.3) - though elsewhere he does select the most plausible stories (e.g. I.214.5). Grasping the inescapably mediated and fragmented nature of his story is an essential part of understanding Herodotus' view of history.

The problems that Herodotus poses to the narratologist are even more acute because he is the first historian whose work we possess in full. The extraordinary variations in his temporal ordering seem the more striking for their contrast with Thucydides' season-by-season narrative of the Peloponnesian War. We do have fragments of earlier or contemporary writers such as Charon of Lampsacus and Xanthus of

\footnotetext{
Marincola 2002: ad loc.

${ }^{3}$ Cf. Groten 1963 and Lateiner r989: 84-9o for basic discussion and listing of variants, and Luraghi 200I for analysis of the metanarrative.
} 
Lydia, but concerted narratological analysis of their handling of time is impossible. If we did possess more of these writers, our own story of time in Greek historiography might be rather different.

\section{Frequency}

Herodotus departs from a singulative frequency most often in iterative summaries such as his account of Croesus' conquests: 'the Ephesians were the first Greeks Croesus attacked, but afterwards he attacked all the Ionian and Aeolian cities one by one. He always gave different reasons for doing so ...' (I.26). This sort of iterative summary is more common in the earlier books, when Herodotus is describing the more distant past. Compare, for instance, his account of Cyrus' conquests in inland Asia: 'While Harpagus was laying waste to coastal Asia, Cyrus himself was doing the same in inland Asia. He systematically defeated every tribe, passing over none (ouden parhieis). I will pass over (parhēsomen) most of these ...' (I.I77). Here the use of the same verb draws attention to the contrast between Cyrus' systematic conquest of inland Asia and the selective treatment in the narrative. The selectivity of the narrative stands in opposition to Cyrus' ruthless quest for totalizing power. At the same time, the narrative remains in thrall to Cyrus' heroism: Herodotus will narrate those events that gave Cyrus 'the most difficult time (ponon pleiston) and were the most noteworthy (axiapēétotata)'.

The handling of iterative narration causes Herodotus some problems when it conflicts with the ordering of his narrative by kings - that is to say, when a repeated action is carried over by one king from his predecessor. All that Herodotus reports under the reign of the Lydian king Sadyattes is that he succeeded his father, reigned for twelve years, and was succeeded by his son Alyattes (I.I6). It is in recounting Alyattes' reign that Herodotus reveals more about the father:

Alyattes inherited from his father a war between Lydia and Miletus. This is how he used to conduct the invasion of Milesian territory ... they would destroy the fruit-trees and the crops and then return home ... This is the way he conducted the war for eleven years ... For six of the eleven years Sadyattes the son of Ardys was still the Lydian ruler and it was he who invaded Milesian territory each year; ... but for the next five years, it was Alyattes the son of Sadyattes who carried on the war.

(I.I7-I8) 
Here the iterative narration of the first eleven years of the war (varied only by a mention of two major Milesian defeats during this time) contrasts with the singulative narration of the decisive twelfth year-when Alyattes made peace with Miletus after being deceived into thinking that the Milesians were faring much better under the invasions than they in fact were. But Herodotus creates some confusion by appearing to attribute the campaign of all eleven years to a single king (epolemee etea hendeka): Waterfield's translation smoothes over the difficulty by making the ambiguous 'Lydian king' rather than 'he' (i.e. Alyattes) the subject of the verb. Herodotus then uses the technique of progressive correction $^{4}$ to modify the impression he has created. Or is that impression itself a suggestive blurring of the two kings, pointing to the continuity between father and son?

Repeating narration tends to be found when Herodotus uses 'headers' or when he makes his characters repeat stories found in the earlier narrative. 'Headers' (from $\rightarrow$ Homer onwards, and $\mathrm{cf}$. the 'initial summary with subsequent elaboration' in $\rightarrow$ Pindar) involve repetition because they introduce a section of narrative by giving its substance in summary form (e.g. 'After this King Darius captured Samos', 3.I39.I, followed by a detailed narrative of how he captured the island). Here the departure from singulative frequency is simply a matter of the arrangement of the narrative. Repeating actorial analepses are more potent: they highlight the way characters are swayed by the urge to imitate, or avoid, precedents. Herodotus does, however, show some concern for avoiding repetition: when he makes Xerxes argue that 'there would be no point in recounting all the victories Cyrus, Cambyses, and my father Darius won, and all the peoples they annexed, because you

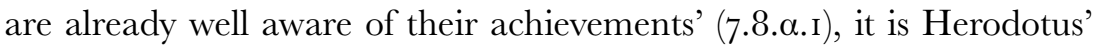
own audience as well as Xerxes' that is aware of the achievements of these kings. ${ }^{5}$ The mere mention is enough to show how Xerxes feels the weight of precedent.

The use of repeating actorial analepsis also hints at how Herodotus' work can be read as repetitive at a deeper level. As the Histories progress, a powerful sense is created that the same story of imperial ambition and overreach is being told a number of different times, and the explicit allusions to earlier examples are part of the way this sense of repetition is created. (There are also links in terms of the repetition

${ }^{4}$ Cf. R. Lattimore 1958 for this technique.

${ }^{5}$ Cf. de Jong 200ib: Io6. 
of narrative patterns, above all connecting Darius' invasion of Scythia and Xerxes' invasion of Greece. $)^{6}$ That is not to say that the singulative aspect does not remain important. Indeed, the singulative supports the repeating: the very fact that Croesus and the various Persian kings differ among themselves highlights more strongly the feature they share - the fact that they all eventually succumb to the expansionist urge and confirm Herodotus' judgement that human prosperity never stays in the same place $(\mathrm{I} \cdot 5 \cdot 4) .^{7}$

\section{Speed}

The transience of human prosperity itself affects the speed of Herodotus' narrative - at least according to a methodological statement placed near the start of the narrative: 'I will cover minor and major human settlements equally, because most of those which were important have diminished in significance now, and those which were great in my own time were small in times past' (I.5.3). It is not clear in practice how this principle affects the speed of the narrative: Herodotus does not in fact cover - or even promise to cover - major and minor settlements with the same amount of detail; his comment is mainly a way of focussing on the theme of human fragility. Herodotus does offer other comments on the space he has devoted to a section of narrative. Twice he claims that the presence of extraordinary monuments is a reason for expanding his coverage of a place (2.35. I on Egypt; 3.60.I on Samos). ${ }^{8}$ More commonly he draws attention to ellipses. We have already seen the contrast between the singulative and iterative treatment of Cyrus' conquests - where Herodotus says that he will narrate those achievements 'which gave him the most difficult time and were the most noteworthy (axiapēgētotata)'. The same criterion of the noteworthy is found when he writes that Gyges attacked two Greek cities and seized another, 'but he achieved nothing else of significance (mega ... ergon) during the thirty-eight years of his kingship, so I will say no more about him' (I.I4.4). In none of these comments, however, does

${ }^{6}$ Cf. Hartog [1980] I988: 30-35.

${ }^{7}$ Cf. Pelling I99ob: 259; Dewald 2003.

8 There is a difference between the two passages in that the first is placed before, and the second after, the lengthy description: the second in a sense justifies the historian in going on to describe three Samian building achievements. 
Herodotus comment explicitly on the relation between his selectivity and the duration of the actions he has selected. So too Plutarch in his De malignitate Herodoti criticises Herodotus for his judgement of what is eventworthy, not for the relation between textual space and duration (e.g. $858 \mathrm{a}-\mathrm{b} ; 866 \mathrm{c}-\mathrm{d} ; 87 \mathrm{Ib})$. But that is not to say that we should not analyse speed ourselves.

Analysis of speed is hampered by Herodotus' lack of precision. ${ }^{9}$ It is possible to measure the textual space devoted to the reign of different kings against the length of their reigns (which Herodotus often reveals at the end of their reigns). Croesus' fourteen years are covered in 52 OCT pages; Cyrus' reign takes up 64 pages, but its length is unclear; Cambyses' reign of seven years and five months takes up I74 pages; Darius' 36 years are covered in 275 pages, Xerxes' seven years in $25^{1 .}{ }^{10}$ These figures, however, give a distorted sense of the speed of the work, above all owing to the ethnographic and geographic components and to the extensive anachronies found in Herodotus' work. The narrative of Cambyses' reign, for instance, includes I25 pages on Egypt, a section introduced only ten lines into his reign and that itself includes spectacular variations of speed (330 kings are summarized in a page at 2.IOO-IOI).

Some significant trends may still be noted. Like Livy's account of the rise of Rome, Herodotus' narrative slows down as it advancesits expansions matching in some sense the expansion of Persian power (though Herodotus' greater tendency to digress and his ethnographic concerns make the effect less clear-cut than in Livy). The slower narrative of the Persian expeditions against Greece contrasts with the much faster narratives of conquest found in the opening book. As we have seen, it is in the opening sections of the work that Herodotus tends to use iterative, summary forms (see, for instance, the summary of the peoples Croesus had conquered at I.28). The effect of this arrangement is to establish the will to conquer as in some sense the natural path for rulers. The same restless urge for, and fear of, conquest is taken over by

9 On Herodotus' chronology see Strasburger ig65; Cobet 2002.

10 Figures for Croesus, Cambyses, and Darius are given at I.86. I; 3.66.2; and 7.4. Xerxes' seven years are from his accession to the end of the story. Cyrus is more problematic: Herodotus never gives the length of his reign (modern historians reckon it at approximately 29 years); his conquest of Croesus is reckoned here under Croesus' reign; and the pages allotted to his reign here include the accounts of Median kings and of his birth and childhood. His reign after his conquest of Croesus (sixteen years) takes up forty pages. 
later characters but subjected to a more detailed analysis. In particular, the steps through which conquests are achieved are now examined in much greater detail.

Variations in speed on a smaller scale become easier to isolate in the course of the work. Starting with the narrative of the Ionian Revolt, Herodotus does sometimes mark divisions of seasons and years (see, for instance, the indications by year at 6.I8, 3I.I, 40.I, 42.I, 46.I; 9.I2I, and the indication of the start of spring at 6.43.I; 7.37.I; 8.I30.I) ${ }^{11}$ and a break-down by days is found in some parts of the Persian Wars narrative. But at the micro-level of, say, the battle narrative analysis of speed is often difficult because Herodotus tends to offer a series of incidents rather than a continuous narrative - though Plutarch $D e$ malignitate Herodoti 873e did attempt such an analysis of the Salamis narrative: 'he has written more on queen Artemisia than on the rest of the fighting put together' (in fact 32 lines out of I3I). ${ }^{12} \mathrm{He}$ also tends to be vague about how long episodes lasted: $:^{13}$ the fighting at Marathon, for instance, went on for 'a long time' (khronos ... pollos, 6.II3.I), and chronological detail on the preceding and following days is also scarce 6.ro6.I, the runner Philippides reached Sparta from Athens on the second day; ro6.3, it was the ninth day of the month at Sparta - a detail required to explain why the Spartans delay until the full moon before sending help; I07.I, the night before the Persians landed Hippias had a dream; iı, the battle was fought on the day Miltiades held the prytany (but we do not learn how many days had passed since the decision to fight was taken); 120, the Spartan army arrives on the third day after setting out).

\section{Order}

Herodotus' disposition of his material has often been admired (e.g. D.H. Pomp. 3). ${ }^{14}$ As we have seen, he starts with a brief account of the Lydian king Croesus, then goes back to his predecessors before giving

\footnotetext{
${ }^{11}$ Cf. Pohlenz I937: I98-I99; also Bouvier 2000, who rightly warns against attributing to Herodotus the same sort of seasonal perspective found in Thucydides.

12 The calculation of Bowen I992: I47.

${ }_{13}$ Powell 1938 s.v. khronos helpfully lists many of the common temporal expressions used by Herodotus.

14 Modern treatments include Immerwahr i966: 79-147; de Jong 2002; de Jong also focusses on narrative transitions, on which see also Lang I984: I-I7.
} 
a fuller account of Croesus' conquests, leading up to his conquest by the Persian king Cyrus. He then turns back to give one of the stories about Cyrus' birth and to describe his rise to power in Persia and his successes as king. He then describes in succession the reigns of the next three Persian kings, Cambyses, Darius, and Xerxes.

While Herodotus' work has a broadly linear pattern set by the succession of Lydian and Persian kings, it has numerous anachronies, many of them of considerable length. Some shorter instances of analepsis are a mark of deft storytelling - for instance, the type of 'archaic' delay analysed by Fraenkel in a classic note. ${ }^{15}$ An excellent example of Herodotus' use of delay comes in his description of Cambyses' death. When Cambyses heard that one of the magi who rebelled against him was called Smerdis, he 'saw the true meaning of the dream, in which someone had brought him a message that Smerdis was sitting on the royal throne with his head touching the sky' (3.64.I). Stricken with grief for having had his brother Smerdis killed, he leapt on his horse to make for Susa - and as he did so he was wounded with his own sword in his thigh, 'in exactly the same spot that he had previously wounded the Egyptian god Apis' (3.64.3). Realising that the wound was fatal, he asked the name of the place and was told that it was Ecbatana: 'Now, the oracle in Buto had earlier told him that he would die in Ecbatana. He had supposed that he would die of old age in Ecbatana in Media, ... but the oracle, as it turned out, had meant Ecbatana in Syria' (3.64.3-4). Realising that he had misinterpreted the oracle, he announced that this was the place where he was to die. Here Herodotus' handling of time creates an extraordinary sense of destiny. There are two analepses involving repetition of earlier information the dream, the wounding of Apis) in addition to the delayed narration of the Ecbatana oracle. The analepsis about Cambyses' wounding of Apis suggests a possible causal link between that outrageous action and his death. But whereas the dream about Smerdis had to be narrated earlier (3.36.2) to make Cambyses' decision to kill his brother Smerdis intelligible (since that decision was based on a misinterpretation of the dream), the Ecbatana oracle could be left until the moment it was fulfilled $\left(\rightarrow\right.$ Homer). ${ }^{16}$ Or rather, it could be postponed because Herodotus

15 Fraenkel i950: III 805, with Rood I998: 28 n. I2.

16 I.85 is another example of this technique. Oracles (e.g. I.53.3), dreams (e.g. I.I08.I), portents (e.g. 7.37.2), and neglected warnings (e.g. 4.83.I, 7.Io) are also often narrated when they first occur, with proleptic force (though there is still room for sus- 
was not concerned to endow Cambyses' misinterpretation of the oracle with deep psychological significance. The misinterpretations highlight, rather, the general fragility of human reasoning.

Longer analeptic passages are often used to explain characters' actions. When characters are motivated by gratitude or by the desire for revenge, Herodotus tends to pause to explain how the reciprocal bond had been created: when, for instance, he explains that Croesus seeks revenge on Cyrus on behalf of his brother-in-law, he pauses to reveal how the marriage bond had arisen (1.73-74); and when he mentions Syloson's appeal to Darius for help in Samos, he tells the story of how Syloson had once lent Darius a cloak in Egypt before Darius became king and then outlines the situation in Samos that had led to Syloson's appeal (3.I39-I43, all following on from the 'header' 'Darius captured Samos' at 3.I39.I). ${ }^{17}$

A complex example of this technique occurs when Herodotus describes the Spartan expedition against Polycrates, tyrant of Samos. Here the expedition is loosely attached to the narrative of Persian expansion by means of a synchronism: 'At the same time as Cambyses' campaign against Egypt, the Spartans attacked Samos' (3.39.I). There follows a number of connected stories: Polycrates' seizure of power at Samos; Polycrates' ring; exiles from Samos appealing for help from Sparta; variant Samian and Spartan explanations of why the Spartans were ready to help; an account of why the Corinthians were willing to help - through anger at the Samians for helping 300 Corcyraean youths sent to Sardis for castration; and finally an explanation of the origin of hostility between Corinth and Corcyra, which stemmed from the hostility between the tyrant Periander and his son Lycophron. It is only at 3.54 (nine pages after the shift to Samos) that Herodotus recounts the Spartan expedition (which only takes up a page, followed by a page and a half on the Samian exiles). Through the synchronism and the consequent chain of explanation, Herodotus interweaves the stories of two Greek tyrants into his narrative of Persian rulers. The Polycrates narrative highlights the general theme of the instability of good fortune, while the story of Periander and Lycophron interacts with the story of Cambyses by focussing on the difficulty of transmitting rule from father to son (different stories concerned with Periander are deployed elsewhere: the Arion story at I.23-24 and the evils of

pense about how they will turn out); on warners see R. Lattimore I939; Pelling I99I.

${ }^{17}$ Cf. in general Gould I989: 42-62. 
his tyranny in Socles' speech at 5.92). At the same time, Herodotus prepares for his later narratives of Polycrates' slaughter by Oroites (3.120-I25) and of Samos' conquest by Persia (3.139-I49). His careful interweaving of Greek and Persian narratives in this section of the work is especially pointed because many of the themes are brought together in the Persian constitutional debate $(3.8 \mathrm{o}-82) .{ }^{18}$

Another common pattern is for Herodotus to describe foreign lands as the Persians try to conquer them or when embassies are sent to them. While such descriptions tend to be geographical and ethnographical, they do also often have a narrative component, especially in the long account of Egyptian kings in book 2. There is also a narrative component when Herodotus explains the origins of customs (e.g. I.94 on the Lydian invention of games during a draught). These analeptic passages are more common in the earlier books. In the account of Xerxes' expedition, background information about places tends to be given as Xerxes arrives at them. But the analeptic technique is used, for instance, when Herodotus describes the origins of Gelon's tyranny at Syracuse in the context of the Greeks' appeal for help to Gelon (7.I53I56).

One effect of the long descriptive passages of foreign lands found in the earlier books is to create a sense of a pause: as we have seen, the account of Egypt is far longer than the account of Cambyses' own achievements. The sense of a pause created by ethnographic sections can be read as a sign of resistance on the level of the narrative to the forward momentum of Persian expansion. ${ }^{19}$ Yet Herodotus' long account of Egypt also highlights what is at stake for the Persians, explaining why they want to conquer Egypt and placing their ambitions within the traditions of Egyptian history. So in another sense Herodotus' long analeptic account of Egypt panders to the spirit of Persian expansion. Indeed, his account of Egyptian kings itself pays attention to their urge to construct lasting monuments for themselves, and there are even two internal prolepses that reveal how Darius sought to establish himself as heir to the Egyptian royal tradition: he wanted to place a statue of himself in front of a statue of Sesostris but was prevented by a priest who claimed that his own conquests were dwarfed by those of Sesostris (2.110); and he finished the canal to the Red Sea that had been started by an earlier Egyptian king (2.158).

18 Cf. Pelling 2002b.

19 Cf. Payen i995. 
Especially adroit is the way Herodotus fills in the stories of Athens and Sparta in the course of the work. He includes analeptic narratives of Athenian and Spartan history first when Croesus seeks to make an alliance with the most powerful Greek state (I.56-70); later when Aristagoras seeks support for the Ionian Revolt in Sparta and Athens (5.39-48, 56-96); and finally when Persian envoys are sent to seek the submission of the Greek cities in Europe (6.5 $\left.\mathrm{I}^{-93}\right)$. Herodotus highlights in this way the two leading Greek states in the Persian Warsand the two states who were at war at the time when he was finishing his work. He could easily have arranged the material differently: since Croesus also made alliances with the Egyptian king Amasis and with the Babylonians, Herodotus could have exploited those alliances to introduce accounts of the situation in Egypt and Assyria. As it is, he only mentions those alliances analeptically (I.77.2), and he gives his descriptions of Egypt and Babylon when they are conquered by Persia.

Particularly distinctive of Herodotus is the use of anachrony in what some critics have thought equivalent to modern footnotes or endnotes. ${ }^{20}$ Herodotus often pauses to give interesting anecdotes connected with people mentioned in the narrative or with members of their family. He narrates, for instance, the punishment and revenge of Euenius, the 'negligent nightwatchman', introduced as the father of a character mentioned in the narrative $(9.93-95) .{ }^{21}$ Often the placing of these apparently incidental analepses or prolepses seems telling. We have already seen that Herodotus closes his work with an anecdote concerning an ancestor of the Persian Artayctes, who has just been crucified by the Athenians (9.I22). Many critics have noted how this anecdote provides a closure (though not a resolution) to major themes in the Histories: the contrast of 'hard' and 'soft' nations and the effects of environment and luxury. An example of a suggestive prolepsis introduced through a family relationship occurs when Herodotus relates that Aristagoras in his desire to become tyrant of Naxos persuades the Persians to send an expedition against Naxos, and that the command of this expedition is given to Megabates: 'Years later - if there is any truth to the story-Pausanias of Lacedaemon, the son of Cleombrotus, wanted to become the tyrant of all Greece, and he got himself betrothed to Megabates' daughter' (5.32). This external prolep-

20 Myres 1953: Io9 (with the italicised parts of his useful 'Tabular Analysis' of the Histories on pp. I $18-\mathrm{I} 34)$.

21 Cf. A. Griffiths i999. 
sis is an explicit hint of a topic only hinted at obliquely in the later narrative - the medism of Pausanias, the victor of Plataea. In its context, the prolepsis hints at parallels between Aristagoras and Pausanias: 'The lush Ionian and the archetypally unspartan Spartan are juxtaposed just as the gaze returns to the West, destabilising any univocal picture of Ionian/eastern luxury and Spartan hardiness'. ${ }^{22}$

Herodotus' prolepses often have an overtly moral point. He frequently looks ahead to the punishment of characters for the action they have just performed (e.g. Oroites' comeuppance, described at 3.126I28); he also digresses specifically to describe a punishment inflicted by a character mentioned for other reasons $\left(8.105^{-106}\right.$, the eunuch Hermotimus forcing the man who had castrated him to castrate his own sons and be castrated by them in turn). ${ }^{23}$ Such instances of 'proleptic closure' ( $\rightarrow$ Thucydides, $\rightarrow$ Xenophon, $\rightarrow$ Herodian) show the importance of reciprocity as an organising principle in Herodotus' narrative, but they may still interact suggestively with their contexts. The story of the revival of the anger of the herald Talthybius during the Peloponnesian War - when the Athenians execute the sons of the Spartan heralds sent to make amends for the execution of Persian heralds (7.I37) - is placed just before Herodotus' praise of the Athenians for not abandoning their fellow Greeks or surrendering to Xerxes (7.I39). This external prolepsis is, as we have seen, one of a number of anticipations of the later conflict between the two great victors of the Persian Wars. Here the prolepsis moulds the narratee's response to Herodotus' praise of Athens - especially as Herodotus claims that he expresses that opinion 'despite the fact that it will offend a great many people', another hint at Athens' later unpopularity.

Prolepsis is also used to undercut apparent moral approval of Athens when Herodotus describes how the Athenians yield command of the sea to the Spartans. Herodotus uses a generalization to present this action in a positive light: 'what was important to them was the survival of Greece and they knew that if they made leadership a point of dispute, Greece would be lost. And they were right, because internal dissension is worse than a united war effort to the same degree that war is worse than peace' (8.3.I). But he then subverts this praise with an allusion to Athens' later imperial ambitions: 'it was appreciation of this fact that made the Athenians give way without making a fuss-

\footnotetext{
22 Pelling I997: n.p.

23 Cf. S. Hornblower 2003. Another instance is 7.213.2 (death of the traitor Epialtes).
} 
but, as they later demonstrated, only for as long as they badly needed the rest of the Greeks. Once Xerxes' invasion had been repulsed and they were fighting for his territory rather than their own, they deprived the Spartans of the leadership, using Pausanias' arrogant behaviour as a pretext. But all this happened later' (8.3.2). Anachrony is here used to deepen the narratee's understanding by setting actions in a broader historical context.

Analepsis and prolepsis are subversively combined in Herodotus' defence of the Alcmeonids against the charge of signalling to the Persians at Marathon (6.I2I-I3I). Herodotus relates the history of the family, starting with Alcmeon gaining his wealth from Croesus, and looking ahead as far as the birth of Pericles. The details he gives about the past and future of the family pointedly undermine the narratorial defence of the Alcmeonids. Herodotus hints at a progression from the liberty won at Marathon to the quasi-tyrannical position of Pericles at Athens. ${ }^{24}$

Some anachronies are introduced with no apparent narrative justification. Alan Griffiths has aptly commented on the strange story of how the Persian king once blocked the outflow of some rivers on a high plateau that 'it is difficult to find any obvious reason for its standing where it does' (3.II7; an analepsis followed by iterative narration of how the tribes affected pay each year for the sluice-gates to be opened). Griffiths has, however, noted structural parallels with the narrative that immediately follows: the anachrony is 'a kind of allegorical overture to the main theme, a hydrological metaphor for ... Persian Machtpolitik' ${ }^{25}$

Anachronies are most obviously justified when they are required to deal with simultaneous events. We have already seen that the Polycrates saga was introduced through a synchronism (3.39.I). Here the new story-line was not demanded by the context and the synchronism is a very loose one (a genitive absolute with a present participle). ${ }^{26}$ That looseness is typical of Herodotus' technique even when events are interconnected: the Thermopylae/Artemisium narratives are connected only by men ... de clauses (7.239.4-8.I.I); it is only later that Herodotus reveals that the decisive battles happened on the same days (8.I5.I). The battle of Mycale, by contrast, is synchronized with Plataea

24 Thomas I989: $264-272$.

25 A. Griffiths I999: $176-\mathrm{I} 77$.

${ }^{26}$ Cf. 3.I50.I for a similar technique; also 3.I20.I for a new narrative strand synchronized with an earlier stage of the narrative (Cambyses' illness - when the main narrative has moved on well beyond his death). Immerwahr ig66 has much detailed analysis of these structuring techniques (cf. esp. 59-6I for simultaneous events). 
from the start ('It happened that on the same day as the Persian defeat at Plataea ...', 9.90.I); the narrative then goes back in time to give the antecedents to the battle, and the exact synchronism is resumed only at 9.100 - where the reason for the precision becomes clear: it is a miracle that reports of the victory at Plataea were heard on the same day at Mycale. In general, connection between narrative strands is brought out as is needed for events to be understood - and that is often as characters discover information about the enemy (e.g. 7.I45.2, I72.I, I77; 8.50.I).

There is no room here to consider any other of the anachronies that give the Histories their distinctive texture - and that undermine by their frequency and extent the very attempt to separate out a main narrative from anachronic digressions. In almost all of the anachronies it is possible to read rich thematic resonances. ${ }^{27}$ One general feature that should be noted, however, is that Herodotus is often vague about the scope of his anachronies. Cylon's attempt at tyranny in Athensintroduced to explain the Cylonian curse (5.7I) - is merely said to be 'before the time of Peisistratus' - that is, before the time of the first actual tyranny at Athens. When the inclusion of anachronies is justified by the pattern of reciprocity, even that degree of temporal precision tends to be superfluous (cf. e.g. 5.82-88, the account of the origin of hostility between Athens and Aegina: here a general sense of the past is produced only by the allusion to a change in clothing customs among Athenian women, but that sense of distance is in relation to the narrator's present). ${ }^{28}$

It remains to consider actorial anachrony. I have already noted that many arguments in speeches involve allusions to the past, with some repetition of the earlier narrative - though often the presentation of earlier events is distorted by the speaker's rhetorical needs. These actorial analepses bind together Herodotus' diffuse narrative. There are also occasions when characters tell stories not found elsewhere, as when Solon tells Croesus the stories of the most fortunate men (Tellus the Athenian and Cleobis and Biton). The scope of these anachronies is not given (in the Tellus narrative there is only a reference to a war between the Athenians and their neighbours in Eleusis; the fact that

27 There are many suggestive remarks in Dewald 1998.

${ }^{28}$ Scholars have generally been interested in Herodotus' shifting levels of detail for what they reveal about the nature of the oral tradition with which he was working: cf. e.g. Thomas 2001 . 
Tellus is buried on the site where he fell may also convey a general sense of the past, since it contrasts with the procedure for burying the war dead in Athens described at Thucydides 2.34). The reason is not that the scope of the analepsis is not relevant to its explanatory power, as in the narratorial analepses mentioned above. Rather, the stories are timeless paradigms. Another paradigmatic narrative told by a character is the story of the punishment of Glaucus for asking the Delphic oracle whether he should keep some money left in his keeping (6.86). This story is told by the Spartan Leotychidas when the Athenians refuse to return men left in their safe keeping. Here the scope of the analepsis is given: 'three generations back'. The precision helps bring out the moral of the story: 'today there is not a single descendant of Glaucus alive, nor is there a single household that is considered to stem from Glaucus'. The moral would evidently be weaker if the story were undated or placed further in the past.

A slightly different use of paradigmatic narrative is Socles' story of the origins of the Cypselid tyranny at Corinth and of the crimes of Periander $(5.92$, completing the stories of Periander told by the narrator earlier in the Histories). That a Corinthian tells this story as a warning to the Spartans not to reinstate tyranny at Athens is given an ironic twist by the implicit parallel between the situation in Herodotus and the events leading up to the Peloponnesian War - when there is again fear of increasing Athenian power, but now it is the Corinthians who take the lead in pushing the Spartans to overthrow the tyrant city, Athens.

Socles' story forms a fitting end for this chapter because, as we have seen, it is from the dynamic interplay between the perspectives of participants and narratees in past and present that Herodotus' handling of time derives much of its force. And it is for that reason that order has received much more attention in this chapter than frequency or speed. It is pointless to judge Herodotus' chronology by the standards of later historians. Rather, his vast work - probably far larger than any other prose work to date - is extraordinary for the way it maintains coherence even as it constantly brings in the past and future as a way of forming links, many of them unexpected, and deepening our sense of the uncertainties as well as the regularities of human achievement. 